\title{
DOS IINVENCIONESII: EL CRISTO DEL AUXILIO DE MARTÍNEZ MONTAÑÉS Y EL FELIPE IV A CABALLO. ORÍGENES Y ECO ARQUUTECTÓNICO DE SU DIFUSIÓN EN LIMA *
}

\author{
TWO “INVENTIONS": THE CHRIST OF HELP BY MARTÍNEZ MONTAÑÉS AND THE PHILIP IV ON \\ HORSEBACK. ORIGINS AND ARCHITECTONIC EFFECTS DURING THEIR DIFFUSSION IN LIMA
}

\author{
LEONARDO MATTOS-CÁRDENAS ${ }^{[\star]}$ \\ Istituto di Studi Urbanistici Latinoamericani (Roma-Italia) \\ leomattoscardenas@yahoo.it \\ Fecha de recepción: 13 de enero de 2019 \\ Fecha de aprobación: 26 de abril de 2019
}

\section{RESUMEN}

En el presente ensayo se analizan dos obras relacionadas con Juan Martínez Montañés (1568-1649): su famosa escultura del Crucificado (1603) que fuera destinada a un retablo de la iglesia de Nuestra Señora de la Merced en Lima y cuya estructura original en su versión pictórica (hoy recuperada) dio origen a un grabado (1739), y la parcial contribución del Montañés al Felipe IV a caballo; confrontando la fortuna iconográfica de ambas «invenciones» y su poco conocida presencia en el escenario urbano de la ciudad de Lima.

\section{PALABRAS CLAVE}

Lima; iconografía; manierismo; Barroco

\begin{abstract}
In the following essay, two masterpieces by Juan Martínez Montañés (1568-1649) are analysed: his famous sculpture of the Crucified (1603), which was destined for a retable at the church of Our Lady of Mercy in Lima and whose original pictorical version (already recuperated) gave origin to an engraving (1739), and his partial contribution to the Philip IV on horseback; confronting the iconographic fortune of both "inventions" and their little-known presence in the urban scenery of Lima.
\end{abstract}

\section{KEYWORDS}

Lima; iconography; mannerism; Baroque

\footnotetext{
$\left.{ }^{(* *}\right)$ La presente publicación es producto de una de las líneas de investigación personal de auspicio propio y constituye un esfuerzo más que se suma a los que desde la década del 70 -pero con especial énfasis durante los últimos 15 añosviene llevando a cabo el autor del presente artículo por dar a conocer y analizar el inédito material histórico del que dispone en su archivo romano.

(*) Arquitecto por la Universidad Nacional de Ingeniería y Arquitecto, con mención en Historia, por la Universidad La Sapienza de Roma con estudios de posgrado y obras como restaurador de monumentos y urbanista; dedicado igualmente a la investigación histórica. En Roma ha trabajado en la Oficina Técnica de la Camara de Diputados (19801994) y como experto en gestión cultural en programas de Cooperación Internacional al Desarrollo del Ministerio de Asuntos Exteriores con el Instituto Ítalo-Latinoamericano (IILA). Profesor en el Centro Internacional para la Conservación de Bienes Culturales (ICCROM) y en la Universidad La Sapienza, así como en la Facultad de Arquitectura, Urbanismo y Artes de la Universidad Nacional de Ingeniería de Lima (FAUA-UNI). Autor de los libros Lima y la Plaza de Armas. Historia y aportes de Emilio Harth-Terré (UNI, CAP LIMA, 2017) y Urbanismo andino e hispanoamericano. Ideas y realizaciones 1530-1830 (FAUA-UNI, 2004), y de numerosos artículos, además de conferencias de su especialidad en Europa y América Latina
} 
En relación con el patrimonio edificado, desde hace algún tiempo se estudia la influencia de ciertas esculturas en la ciudad y, en el caso limeño, la de algunos retablos en sus fachadas. Es así como una reciente entrega realizada por la viuda del arquitecto José Correa Orbegoso al convento de La Merced de un lienzo que reproduce un retablo de dicha iglesia con la escultura del Cristo del Auxilio motiva el presente estudio. Esta última fue una invención (estética) de Juan Martínez Montañés (1603) —un Crucificado con cuatro clavos que cruza las tibias de forma insólita- y que fuera destinada a Lima. Este hecho obliga a investigar su obra con el retablo que la alojó - que hoy no existe-, y concluyo que dicho retablo inspiró la fachada del mismo templo mercedario.

La arquitectura limeña surgió así con la contribución fundamental de la madera, con muros y tabiques hechos de dicho material, cañas y barro - formando la quincha o bahareque - a los que se añadió el yeso en la Colonia. En esa época aparecieron en las fachadas los balcones cerrados y balaustras talladas en madera, mientras que en el interior de sus templos se armaban - con la misma técnica- bóvedas, cúpulas e incluso columnas. Se construyeron retablos, sillerías y motivos artísticos en madera, que directamente se transferían a las fachadas, tallándolas incluso en piedra. Vemos, por ejemplo, en la iglesia de San Francisco «tríos de columnas» $y$ «portadas-retablo con cornisa abierta»' motivos arquitectónicos de retablos que se repiten en las fachadas.

De otro lado, descubro que Juan Francisco Rosa —quien grabó en 1739 el lienzo mercedario que hoy nos ocupa - fue un excelente pintor, «matemático y experto en fortificaciones» - coautor del Real Felipe del Callao- llamado por el virrey Manso de Velasco a raíz del terremoto de 1746.

Regresando a la obra del Montañés, analizo su participación en la estatua ecuestre del rey Felipe IV — decidida en Madrid y hoy allí visible-cuyo caballo por vez primera apoya solo posteriores y la cola. Otra invención (técnica) que adopta Baltazar Gavilán en su Felipe V a caballo para colocarla sobre el arco del Puente de Piedra en Lima, que aparece en una propuesta para el Paseo de Aguas — no realizada — de probable mano del virrey, y que adopta finalmente Adamo Tadolini para esculpir su Bolívar a caballo -instalado a mediados del ochocientos — en la homónima plaza.

Y sobre el gran Montañés —escribía ya el recordado Jorge Bernales Ballesteros (1981)— «puede comprobarse que el estilo y los modelos iconográficos de Juan Martínez Montañés fueron decisivos para la escultura indiana; y considerar al famoso maestro, como bien lo definió el Marqués de Lozoya:"padre de la escultura del XVII en Hispanoamérica”» (p. 502)².

\section{Una «invención» (estética): el Cristo del Auxilio y su eco en Lima}

El Crucificado se ha interpretado de diferentes modos; incluso existe la versión con un solo madero, que nace de la palabra griega stauros a la que se remiten para hablar de «estaca» - o viga simplemente vertical_ - hoy vigente en confesiones que no reconocen la cruz convencional, de unánime aceptación, con dos maderos que se cruzan en ángulo recto - que es el caso que nos ocupa ${ }^{3}$ - siendo menor el madero horizontal, donde el Crucificado presenta cuatro llagas — una en cada extremidady a veces una quinta, al costado.

El Crucificado, desde que empezó a ser representado hasta el siglo XII, tuvo siempre las piernas en forma paralela y cuatro clavos. En efecto, doctores de la Iglesia (Ireneo, Justino) decían que fueron cuatro los clavos de la crucifixión. Pero - alternando con los

\footnotetext{
1. Temas estudiados por el recordado historiador Antonio San Cristóbal.

2. Ocasión en que cita el artículo del Marqués de Lozoya (1971, p. 65).

3. Existe, además, la llamada «cruz de San Andrés» (en X) y la de forma de Tau (T) que se excluyen, igualmente, del presente análisis.
} 


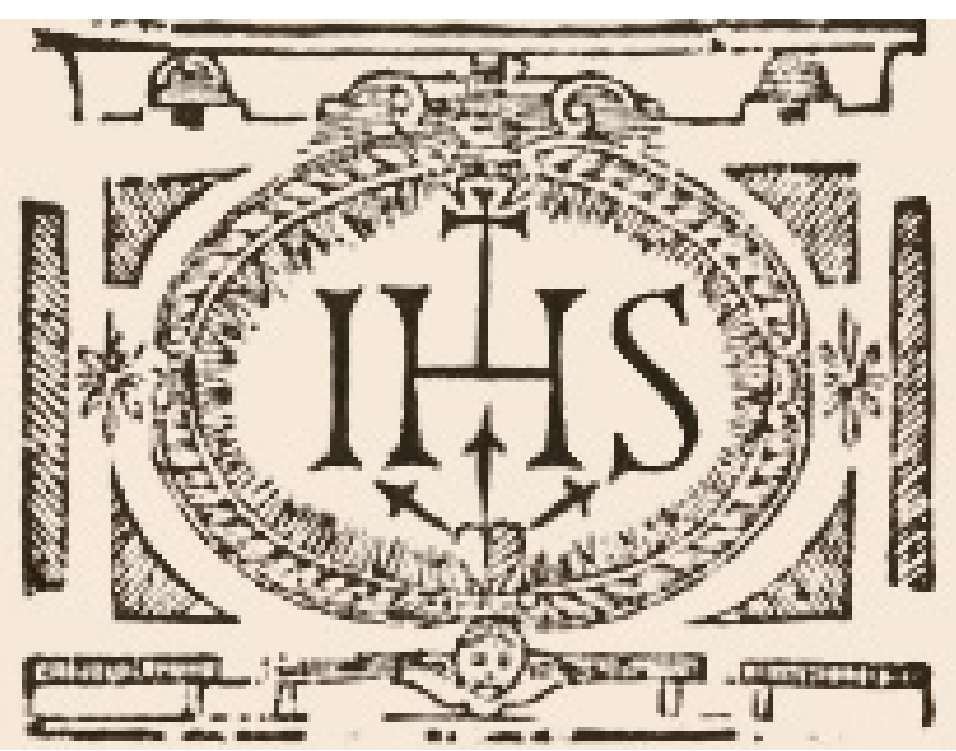

Figura 1. Los «tres clavos» del trigrama de la Compañía. Detalle de la portada de un libro escrito por el jesuita Holguin (Lima, 1608)

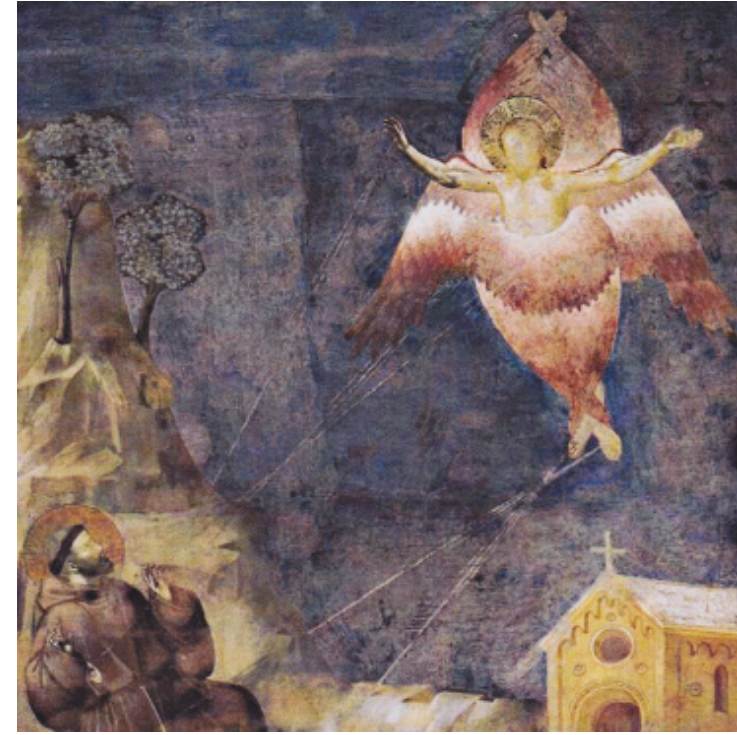

Figura 2. Giotto, San Francisco recibiendo los estigmas del Seraffin (Asis, Italia; s. XIII).

precedentes- en el siglo XII aparecieron Crucificados con tres clavos, donde un solo clavo atraviesa ambos pies, más ágiles y esbeltos, pero con otro significado numerológico -y quizás bíblico-; acusados, incluso, de ser maniqueos y judaizantes. De esa acusación tuvo que defenderse el mismo Ignacio de Loyola, fundador de la Compañía, cuyo emblema tiene tres clavos bajo la cruz - y hoy forma parte del monograma papal — viniendo del trigrama de la orden aprobado en 1540 (ver Figura 1).

A mediados de 1372 - cuando convivían ambas versiones - aparecieron las Revelaciones de Santa Brígida, difundiéndose con la aparición de la imprenta, el siglo siguiente. La mística sueca narra que «abierta su mano derecha, la colocaron sobre la cruz, y [...] la crucificaron, perforándola [...]. Después, [...] la mano izquierda, de la misma manera la fijaron a la cruz. Seguidamente [...] crucificaron con dos clavos los pies» (Libro 7, cap. 15). Pero la variante que nos ocupa -i.e. Cristo con cuatro clavos y con las tibias en $\mathrm{X}$ - viene de otra visión de Brígida: «Alzaron el brazo izquierdo y clavaron la mano a la cruz de igual modo [...]. Después, crucificaron el pie derecho y encima pusieron el izquierdo, con dos clavos» (Libro 1, cap. 10)4.

Estoy convencido de que Brígida, terciaria franciscana, tuvo esta visión - con pies cruzados - viendo, en 1352, los frescos de Giotto (XIII) sobre la vida de Francisco en Asís. Allí hay uno que lo presenta recibiendo los estigmas del serafín - que tiene sus alas inferiores cruzadas de dicho modo- al punto que, a primera vista, parecen cruzarse las tibias de Cristo, aunque no se crucen ( ver Figura 2).

\section{El Crucificado de cuatro clavos y «pies cruzados» del Montañés}

El primer Crucificado de Martínez Montañés (Alcalá la Real, 1568-Sevilla, 1649) con la tibia izquierda que cruza sobre derecha — como fue descrito por Santa Brígida — fue enviado

\footnotetext{
4. Traducción propia. Versión italiana accesible online digitando: «Revelazioni Santa Brigida». En efecto, la frase dicha al último es la siguiente: «Poi crocifissero il piede destro e sopra vi misero il sinistro, con due chiodi».
} 


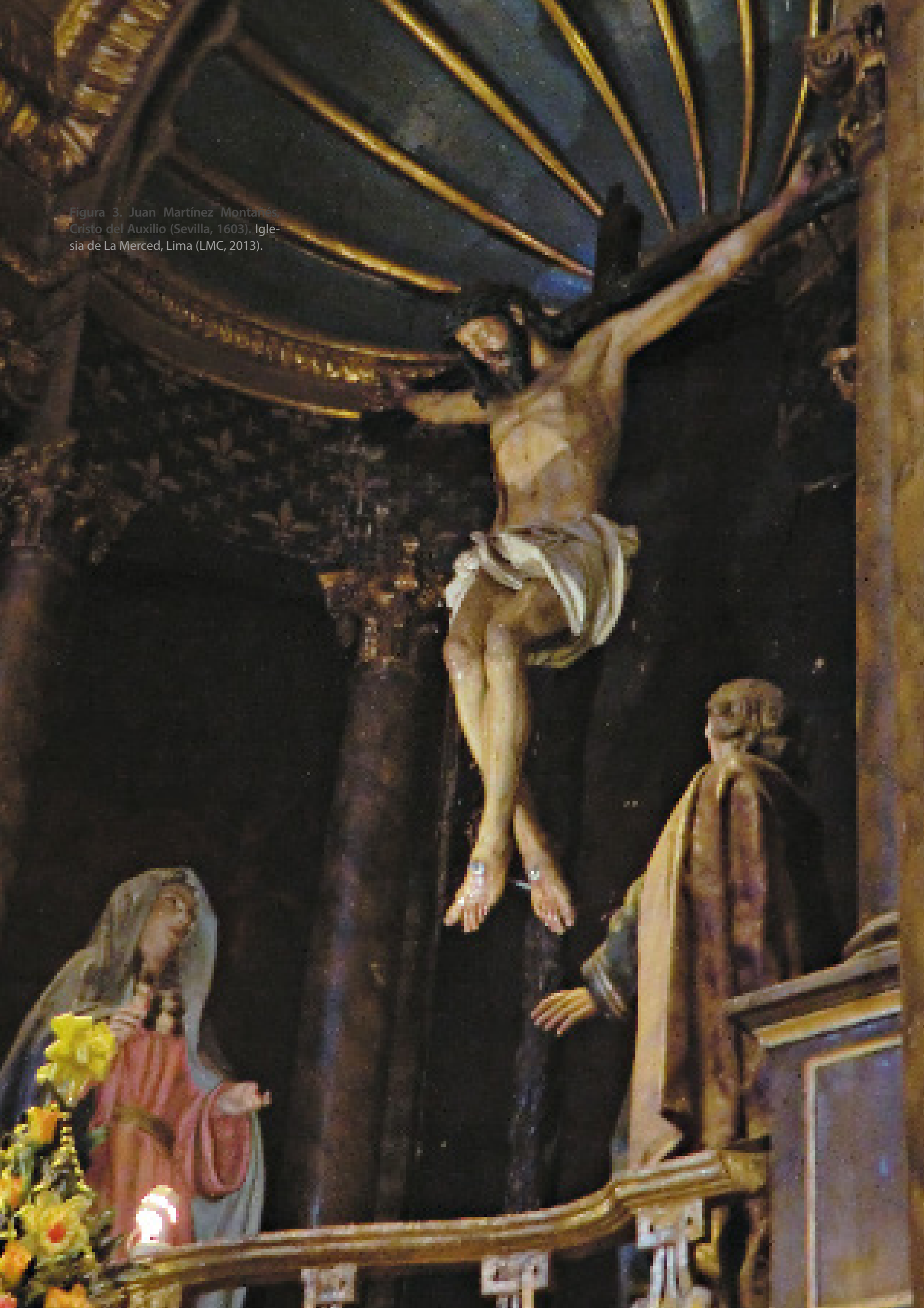


a Lima (1603) y hoy es llamado Señor del Auxilio, de elegante trazo manierista, alargado, de esquema dinámico casi trapezoidal, difunto y con cinco llagas ( ver Figura 3).

Dicha invención de un Cristo muerto - con las tibias que se cruzan- después tuvo variantes: por su mirada, si está vivo, o por la posición de la cabeza, que duplican si las tibias se cruzan al contrario. Así, Montañés, una vez acabado el Cristo destinado a Lima, suscribió otro pedido: «Ha de estar vivo antes de haber expirado [...] mirando a cualquier persona que estuviese orando al pie; ha de ser mejor que uno que hice [...] para las provincias del Perú [...]. Tengo gran deseo de acabar y hacer una pieza semejante para que permanezca en España $»^{5}$. Fue el sevillano Cristo de la Clemencia (1607), de 1.90 m de alto y tallado en cedro cubano, de composición similar al limeño, pues apoya la cabeza sobre el hombro derecho y tiene el nudo del perizoma a su derecha. Pero es casi dialogante, pues está vivo; sus piernas se cruzan al revés, sin herida al costado y con una corona de espinas natural, amplia. El estofado, policromado y encarnado mate -como probablemente hizo con el modelo limeño- los encargó a su colaborador Francisco Pacheco (Sanlúcar, 1546-Sevilla, 1644), válido pintor y erudito. La escultura sevillana, pedida por el canónigo Mateo Vásquez de Leca para su oratorio, a su muerte pasó a la Cartuja de Santa María de las Cuevas, y desde 1836 está en la Catedral de Sevilla, expropiada por la llamada «Desamortización de Mendizábal». Pacheco escribió un Arte de la pintura —obra póstuma - donde asegura que esculpir un Cristo muerto es más difícil (Pacheco, 1649, p. 56) -evidente referencia al primer modelo limeño-y que tuvo en cuenta las Revelaciones (Pacheco 1649, pp. 592-593) «con la segura opinión de los quatro clavos de Cristo crucificado; por aver renovado en mi tiempo esta venerable i antigua pintura». Dedica su capítulo XV «En favor de la pintura de los quatro clavos con que fue crucificado Christo» (Pacheco, 1649, p. 596), e, incluso, refiere que el mismo escultor Torrigiani —conocido por un incidente que tuvo con Miguel Ángel— trajo a Sevilla un Crucificado ideado por el mismo Miguel Ángel, que tenía los pies así cruzados. Este es un modelo que Montañés conoce por una copia que hizo Jacopo del Duca (1597) antes de dejar Italia. En efecto, el Metropolitan Museum of Art de Nueva York posee una copia similar de Fundidor anónimo sobre modelo de Miguel Ángel s. XVI-XVII en bronce, de $25 \mathrm{~cm}$ de altura ${ }^{6}$ (ver Figura 4)

En una colección privada de Parma (Italia) se observa un óleo sobre madera, Crucifijo con las Marías, Magdalena, y Juan Evangelista - escuela toscana, fines del siglo XV-, donde Cristo cruza la tibia derecha como en el modelo sevillano, que dícese inspirado en frescos que hubo en un cercano convento del medioevo tardío. La presencia incluso de las Marías - María Magdalena, María madre de Santiago, María Salomé- prueba la influencia de esas Revelaciones (ver Figura 5).

En Lima hay Cristos a «X», como el «de la Constricción» —en la iglesia jesuita de San Pedro-, escultura de Martín de Oviedo según Schenone (1980, p. 437) y Bernales (1987, p. 304), difunto, con la cabeza sobre el mentón, cruzando la pierna izquierda, como el modelo limeño montañesino; y el llamado Señor de la Conquista —en La Merced — cruzando su tibia derecha, esculpido a 3/4, vivo, con la mirada frontal alta. Hay posteriores hechos en Lima y Potosí (Bolivia), como el de Gaspar de la Cueva, difunto, con la cabeza en posición frontal, que cruza como dicho primer modelo -entre 1632 y 1650- después de su paso por Lima (de Mesa y Gisbert, 1985, p. 121). Pero otro de Gaspar de la Cueva, en la Catedral de Potosí, mira al corazón (Bernales, 1981, p. 566). En La Paz (Bolivia) hay uno similar pintado sobre madera, del español Francisco Herrera y Velarde, hecho en Potosí (1653), donde vivió hasta morir en 1694; como señalan Schenone (1950) y Mario Chacón (1973). En España, pinta Zurbarán (Museo del Prado, Madrid) un San Lucas pintor ante el Crucificado (1650) que mira a Lucas — a su izquierda — siguiendo el modelo sevillano.

5. Contrato localizado y analizado por Hazañas (1918) en forma pormenorizada.

6. La muestra (2016) Francisco Pacheco. Teórico, Artista, Maestro (Museo de Bellas Artes, Sevilla) presentó otras esculturas reducidas — provenientes de España— derivantes de dicho modelo. 


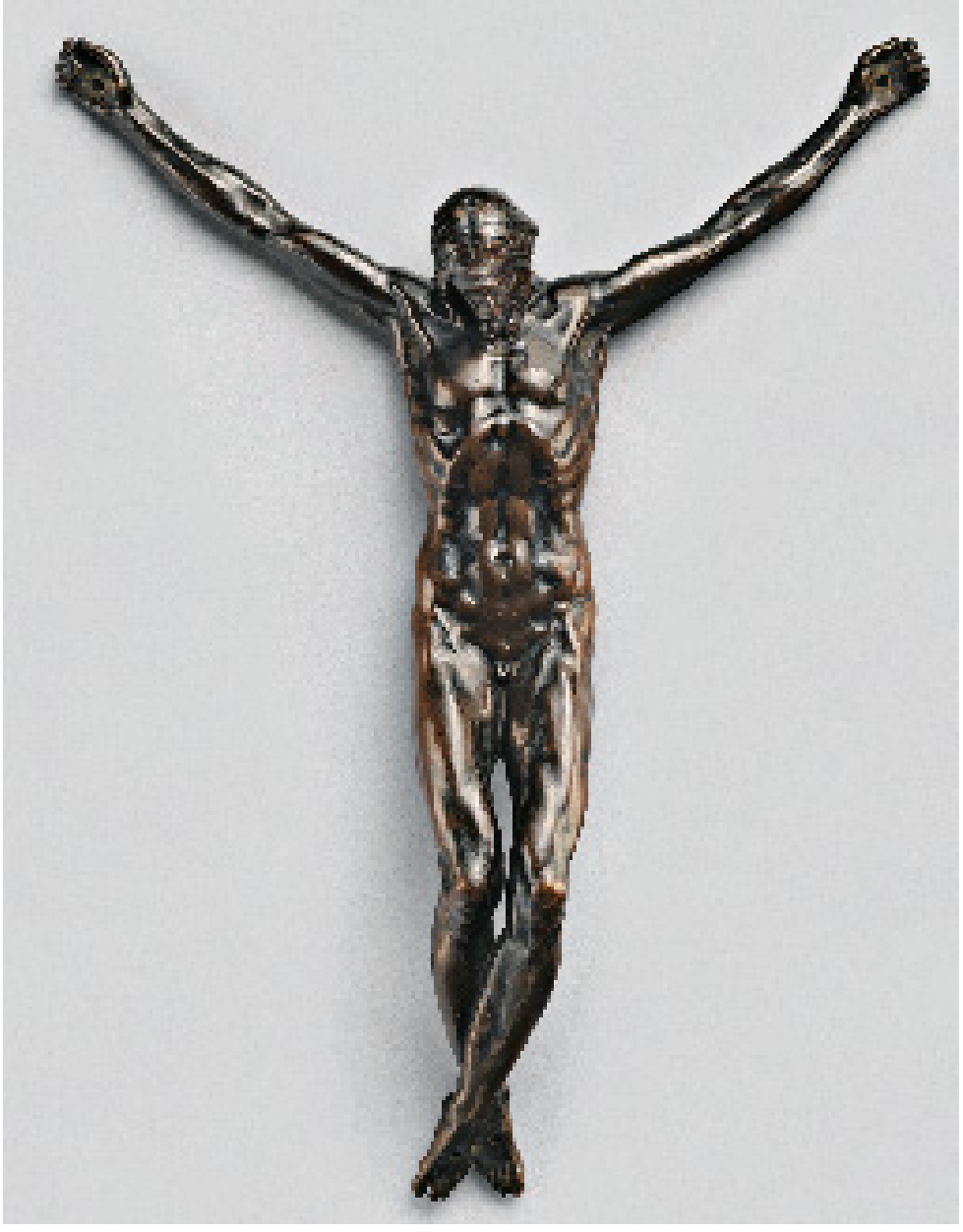

Figura 4. Modelo «que deriva de Miguel Ángel» $25 \mathrm{~cm}$. Metropolitan Museum of Art, N. Y.; N. inv. 37.28 a-d. Recuperado de http://www.metmuseum.org/Collections/ search-the-collections/120012939? rpp $=20 \& p g=2 \& a 0=0 n \& f t=$ thief + cruciG̃ed\&what $=-$ Metal\&pos=21).

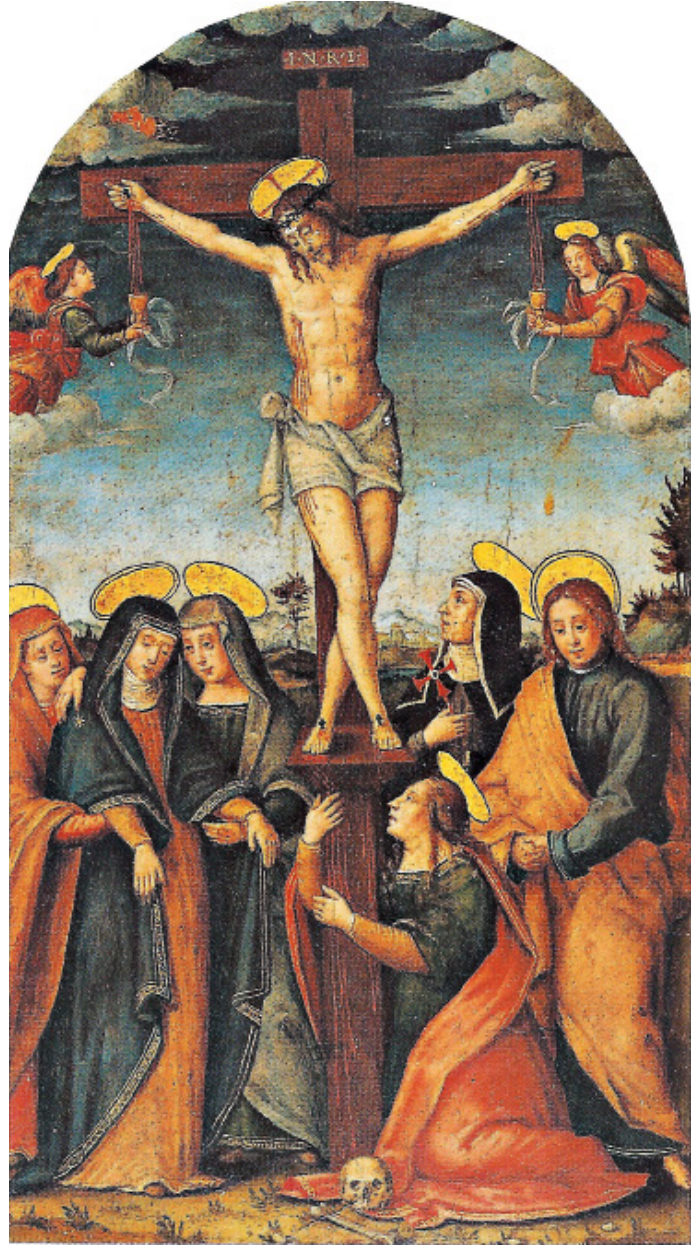

Figura 5. Anónimo, Crucifijo con las Marías, Magdalena y san Juan Bautista (escuela toscana, s. XV). Ólio sobre madera, 44 x 80 cm. Colección Tacoli Canacci inv. 144, Parma, Italia.

En Lima, el «Señor del Auxilio» tuvo gran impacto; allí trabajaban Martín de Oviedo —amigo del Montañés-y Martín Alonso de Mesa (c. 1573-Lima, 1626), ambos sevillanos; desde $1600^{7}$. Harth-Terré (1977) escribía lo siguiente: «por esos años — 1620— [se encarga al dicho] Martin Alonso de Mesa hacerle una imagen de un Cristo descoltura [sic] de la espiración, inclinado el rostro sobre el lado izquierdo, del tamaño del que está en la Capilla de la Redención de Cautivos, de Nuestra Señora de Las Mercedes, de esta dicha ciudad [... incluso para] llevar a la dicha ciudad de Santiago del Chile» (p. 92) ${ }^{8}$. Y en Lima, gobernando el Conde de Lemos, «la noticia de la toma de Panamá ["la Vieja", saqueada en 1670] fue seguida de rogativas en los templos y una procesión que desfiló desde la Capilla Real [de Palacio] a la Catedral, con la Virgen de Los Desamparados y el Señor del Auxilio»?.

\footnotetext{
7. de Mesa y Gisbert de Mesa (1985, p. 114); aunque Ramos Sosa habla de pocos años después.

8. Del Archivo General de la Nación del Perú (AGN, López Lizar, 1620, f. 331).

9. Archivo General de Indias de Sevilla (AGI, Panamá, 78), cita y texto en Basadre (1945, p. 381).
} 


\section{Su Retablo, el lienzo (Lima, siglo XVII) y el grabado (1739) de Juan Francisco Rosa}

El llamado Señor del Auxilio — para Mesa y Gisbert (1985) — fue «aparte de las imágenes de la Virgen [que a Lima llegaron antes...] la obra más temprana de Montañés llegada al Perú» (p. 114). Su Retablo — desde entonces en la iglesia de La Merced— tuvo ricas columnas salomónicas y dos pares de niños atlantes, como se aprecia en el lienzo pintado al temple ${ }^{10}$ que nos ocupa $(1.25 \times 1.87 \mathrm{~m})$, técnica menos empleada que el óleo (ver Figura 6).

Las columnas salomónicas de dicho Retablo no pueden ser del Montañés, pues él nunca las empleó en retablos, como recuerda el amigo Bonet Correa. Harth-Terré (1977) agrega lo siguiente: «Hernández Díaz [...] afirma con énfasis "que en la historia del retablo sevillano, no aparece dicho tipo de soporte hasta $1658^{\prime \prime} »\left(\right.$ p. 89) ${ }^{11}$. Por consiguiente, el dicho Retablo, que es posterior a dicha fecha, tiene un «banco del altar» que termina con una curvatura y seis elaborados portacirios - probablemente de plata-, dos de ellos puestos, altos, sutiles y encendidos. Vemos, debajo del monograma de María — «AMR» — otro elaborado marco rectangular con su delicado retrato de gusto manierista - medio busto y manos juntas - entre otras dos columnas salomónicas más pequeñas.

Sin embargo, hoy dicho Retablo mercedario presenta columnas lisas, neoclásicas, de fines del virreinato; pero conserva relieves de la primera época, atribuidos a Alonso de Mesa y a Juan de Oviedo (Sevilla, c. 1565-Lima, c. 1620) de quien Jorge Bernales (1987) escribe lo siguiente:

Cuatro relieves pasionarios pueden identificarse con los que hoy se ven en el retablo del Cristo del Auxilio, de dicho templo, dedicados a La oración en el huerto, Jesús atado a la columna, Ecce Homo, y Jesús con la cruz a cuestas, todos ellos de un estilo próximo al de Montañés, pero con inequívocos signos manieristas que sindican a Oviedo como un maestro de transición entre el manierismo y primeros síntomas de realismo. (p. 304) ${ }^{12}$

Del primer retablo, de la Virgen y de San Juan — de cuerpo entero-, Harth-Terré (1977) agrega lo siguiente:

En 1612 el maestro Martin Alonso [de Mesa] había recibido de la comunidad mercedaria el encargo de labrar [...] otro [retablo] completo que el maestro colocaría en la capilla del Santo Crucifijo. El concierto [... refiere que] se comprometió [a] colocar en los nichos del primer cuerpo de las calles laterales dos imágenes grandes de bulto de Nuestra Señora y de San Juan Bautista. Luego el Crucificado de esa capilla existía ya, y solo se reemplaza algún viejo altar por otro más de acuerdo con la suntuosidad y riqueza urbanas. (p. 93) ${ }^{13}$

Dicho retablo del Señor del Auxilio —además - fue testigo de la actividad religiosa del mercedario español fray Pedro Urraca de la Santísima Trinidad y del hermano lego mercedario, mestizo, Juan Sebastián de la Cruz (Cajabamba, 1668-Lima, 1721), gran difusor de su culto, quien encargó dicho lienzo como donante, y aparece retratado

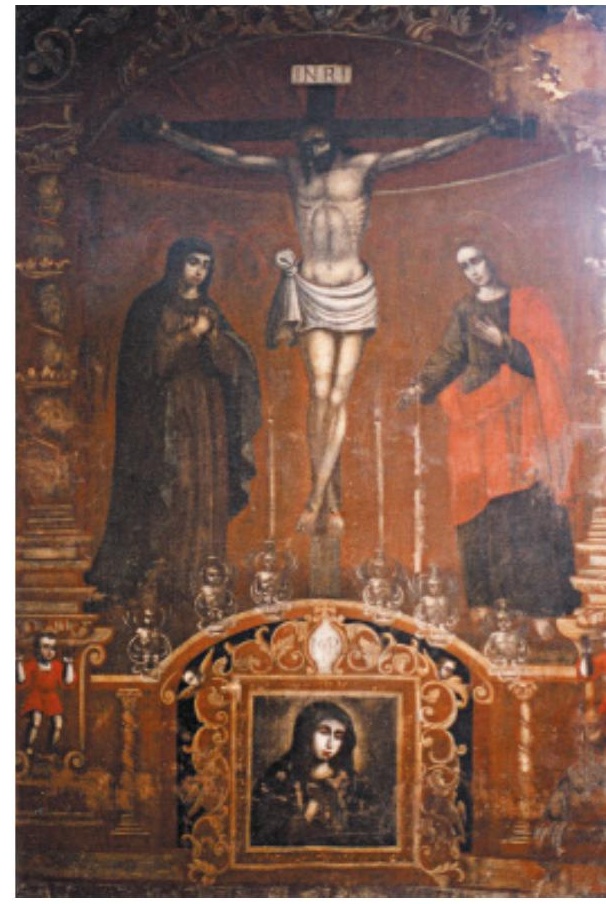

Figura 6. Anónimo, Retablo del Señor del Auxilio (Lima, XVII). Témpera sobre lienzo (LMC, 1992).

10. Dado en pésimas condiciones — al que esto escribe a fines de la década de 1960 — al proyectar la actual torre campanaria exenta al lado de la moderna iglesia de Ate. El colega José Correa lo restauró y encargó un informe - no conocido - a José de Mesa. La viuda Correa — de forma graciosa y noble — lo entregó a La Merced de Lima (marzo, 2018) acogiendo gentilmente mi pedido, y fue recibido por Saul Peredo O. M. amigo creador del Instituto Histórico de su orden en Roma.

11. Harth-Terré escribió dicha frase al estudiar los orígenes de la columna salomónica en el Perú, y leer el artículo Hernández Díaz (1949).

12. Atribución ya de Teresa Gisbert.

13. Harth-Terré cita el Archivo Mercedario, Tomo VIII, f. 125; idem Ramos Sosa (2000, pp. 52 y 58). 


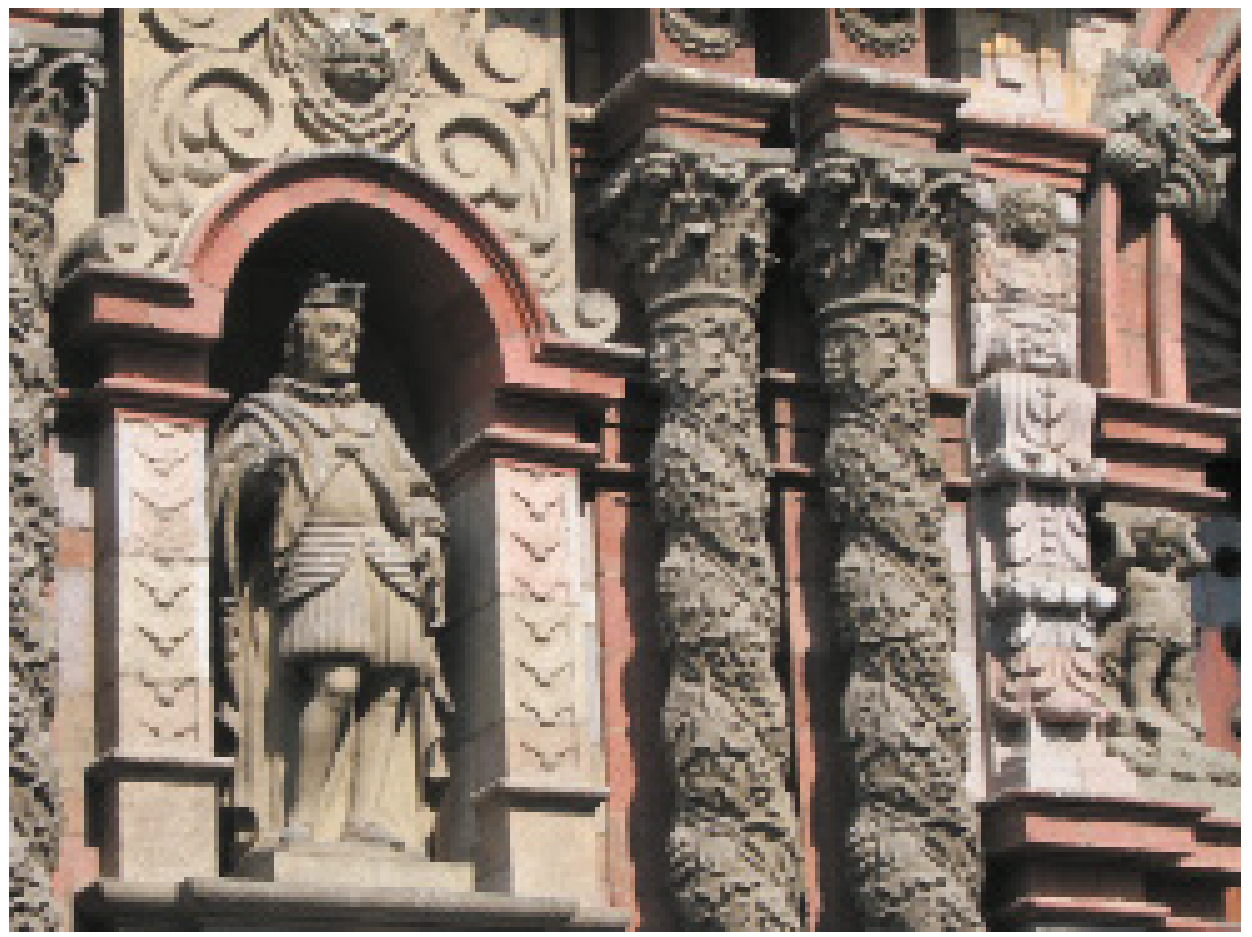

Figura 8. Anónimo, Portada principal de la iglesia de N. Sra. de La Merced, Lima, c. 1687. Nótese las columnas salomónicas y el «niño atlante en pie» (derecha), elementos idénticos a aquellos del antiguo Retablo del Señor del Auxilio (s. XVII) de la dicha iglesia (LMC, 2013).

mercedaria limeña —obra considerada posterior al terremoto de $1687^{17}$ - ; por consiguiente, se asume que dicho retablo y la portada principal de la iglesia limeña de La Merced son obras de un mismo autor, y es evidente que el dicho retablo influenció la traza de su fachada, como sucedió en otros importantes casos. (ver Figura 8)

En efecto, ya San Cristóbal (1994, p. 340) se extrañaba al respecto, porque «se añaden otros niños cargadores, que soportan la rosca del arco exterior de la fachada», suponiendo que dicha fachada fuese obra del mercedario Cristóbal Caballero (San Cristóbal, 1994, p. 336) «arquitecto de retablos» y «maestro de fábrica», condición bastante común entonces. Pero no se ven ni niños atlantes, ni «columnas salomónicas» en la obra conocida de Caballero revisada por Ramos Sosa.

\section{Juan Francisco Rosa, grabador, pintor y «perito en Mathematicas y Forti- ficación»}

De Juan Francisco Rosa solamente se conocían cinco grabados citados por Vargas Ugarte (1968, pp. 455-456): El Señor del Auxilio, Nuestra Señora de las Cabezas (1745) devoción madrileña asociada a San Isidro Labrador-, La Virgen de Copacabana (1746), La Ven. Ignacia María del Sacramento religiosa de la Encarnación y Nuestra Señora de Cocharcas. A ellos agrega Estabridis (2012, pp. 125 y 253) El venerable padre Francisco del Castillo, con vistas del puente de Lima y del Baratillo - en la colección Gunther-y el Túmulo del arzobispo Diego Morcillo Rubio de Auñón de 1744, que ilustra el libro Magnífica parentación, y fúnebre pompa [...] $]^{18}$.

\footnotetext{
17. Aunque desde fines del ochocientos hasta 1939 estuvo oculta bajo capas de yeso; fachada recuperada por Harth-Terré con ayuda del tallador Garcia Monterosso.

18. Grabado de Juan Francisco Rosa: Carter Brown Library, box 1894, record n. 01288.
} 
devenir Vol. 6, №12, JULIO-DICIEMBRE 2019, PP. 27-46 - ESTUdIOS I ISSN 2312-7562 | E-ISSN 2616-4949

UnIVERSIDAD NACIONAL DE INGENIERÍA, LIMA

doi: https://doi.org/10.21754/devenir.v6i12.742

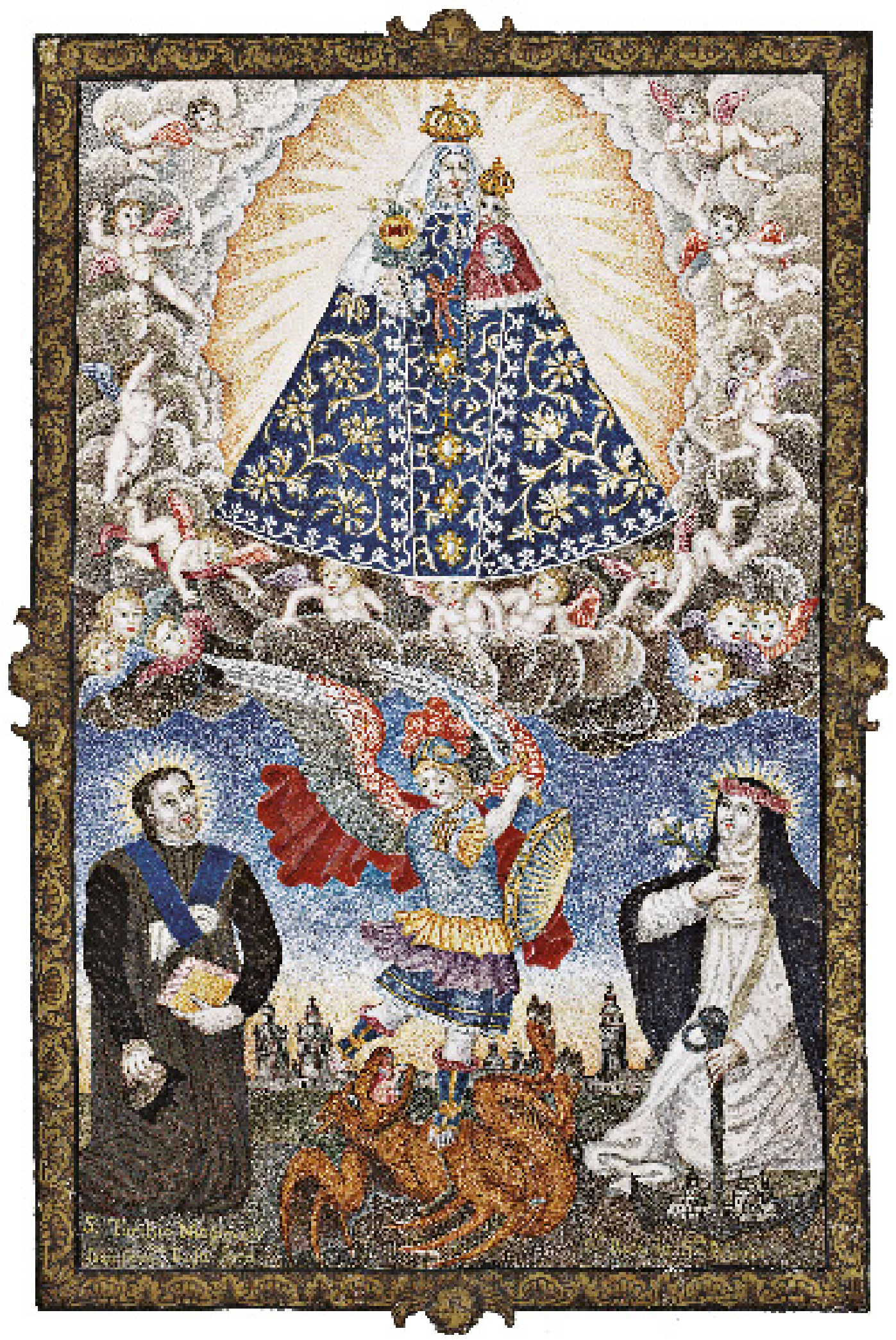

Figura 9. Juan Francisco Rosa, La Virgen y San Miguel arcángel con Santa Rosa y Santo Toribio (Lima, 1749). Al fondo vista de Lima amurallada. Óleo sobre pergamino. 
En el comercio del arte se describe otro ejemplar de dicho libro, con un grabado suyo desconocido que retrata al dicho obispo Morcillo, y se muestra una interesante «Vista de la ciudad de Lima desde el Rímac, con la Virgen del Rosario, y San Miguel arcángel rodeados de Santo Toribio de Mogrovejo y Santa Rosa de Lima», témpera sobre papel firmada por nuestro Rosa, sin fecha, de mediados del XVIII' ${ }^{19}$, así como una bella «Virgen con San Miguel arcángel abatiendo un dragón, ante Santa Rosa de Lima y Santo Toribio de Mogrovejo», miniatura suya $(29.6 \times 21 \mathrm{~cm})$, con Lima amurallada entre torres y edificios de fondo, ilustrando - con otra miniatura de Francisco Meléndez- una «Carta de privilegio y confirmación ${ }^{20}$ con la que Fernando VI da el título de «conde del Valle de Oselle» (Madrid, 5 octubre de 1750) al oidor decano de la audiencia limeña, Alvaro de Navia Bolaño y Moscoso21 (ver Figura 9).

Pude notar que nuestro Juan Francisco Rosa pintó para el oidor Navia Bolaño después de verse a raíz del terremoto de octubre de 1746 en Lima, al hacer transcribir del Archivo de Indias de Sevilla (AGI, Lima, 416) — becado por el Gobierno español en 1987- una carta del virrey, donde Rosa aparece como «perito en Mathematicas y Fortificación» ofreciendo sus pareceres y dibujos.

En efecto, el 16 de abril de 1747, el virrey informó lo siguiente:

Mandé que Don Luis Godin [...] reconociese el Terreno [... y delinease la Fortaleza; y haviendo llegado en la sazón á esta Capital Don Joseph Amich, y Don Juan Francisco Rosa, Peritos en Mathematicas, y Martínez Montañés Fortificación, executaron la misma dilixencia que Godin; y [...] se conformaron en que se construyese un Pentágono, bajo de las reglas y méthodo que verá V. M. por los Planos.

Dicho documento consultado (AGl, Lima, 416) es parte de un llamado «Testimonio de Autos» que estuvo adjunto a «Doce planos del Pentágono [del Real Felipe] que se estaba fabricando en el Presidio del Callao» — hechos a pluma, sin firma, hoy separados como AGl, M y P, Perú y Chile, 29- donde en Lima, ya el 19 de diciembre de 1746, el virrey disponía que: «Don Luis Godin Cathedratico de Matemática y Don Joseph Amich y Don Juan Francisco Rosa ynteligentes en ellas á fin de que conferida por todos dicha fabrica se determine y resuelba, la que sea mas conveniente al Real seruicio y defenza de dicho Presidio». Así, considero entre sus obras el diseño de baluartes del Real Felipe del Callao (ver Figura 10).

El 29 de diciembre de 1746, Rosa se encuentra con Nabia Bolaño -e incluso con Pablo de Olavide-, ya que escribe Diego de Hesles, secretario del virrey, lo siguiente:

Estando en Acuerdo Real de Justicia y Junta de Guerra, el Exselentisimo Señor Don Joseph Antonio de Manso de Velasco [...] y los señores, Don Alvaro Navia Bolaño y Moscoso, [...]; Don Pablo Antonio de Olavide [..., etc.], Presidente y Oidores de esta Real Audiencia; [...] Se vieron los Autos formados sobre la delineación de la fortaleza [...]; en que su Exselensia [sic], por decreto de diez de Noviembre del presente, mandó que Don Luis Godin [...] y asimismo con noticia que tuvo su Exselencia de que paraban en esta Ciudad, Joseph Amich y Don Juan Francisco Rossa, Ynteligentes en Mathematicas y fortificasiones; mandó en véinte y ocho de dicho mes, y el doce del presente, hiciese cada uno por su parte, el Plano necesario para la referida nueva construcción; y [h] abiendo éstos expuesto sobre el asunto sus dictámenes, y Mapas [...] por Decreto de diez y nueve del presente; mandó su Exselencia que le acompañasen [...] los expresados ynteligentes; para que con su asistencia se reconociese el Terreno,

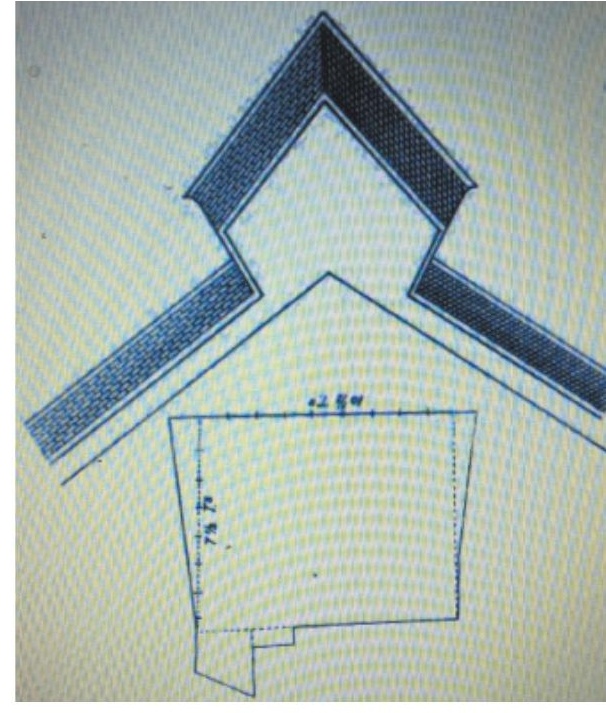

Figura 10. Juan Francisco Rosa, Baluarte de fortaleza pentagonal para el Real Felipe del Callao (Lima, 1746). Dibujo a tinta (AGI, M y P, Perú y Chile, 29).

\footnotetext{
19. Planimetría a colores de Lima de Juan Francisco Rosa, que fuera expuesta durante la feria de 2008, en el stand de don José de la Mano/Galería de Arte, Madrid (www.georginakelman.com).

20. Según referencias del vendedor del expediente: Nueva York, EE. UU., 18 de diciembre de 2003, Christie's lote 138/venta 1318 (www.christies.com).

21. Vargas Ugarte $(1965$, p. 68) escribió que el día 31 de agosto de 1750 le dieron dicho título.
} 
devenir Vol. 6, Nº12, JULIO - DICIEMBRE 2019, pP. 27-46 - Estudios I ISSN 2312-7562 | E-ISSN 2616-4949

UNIVERSIDAD NACIONAL DE INGENIERIA, LIMA

doi: https://doi.org/10.21754/devenir.v6i12.742

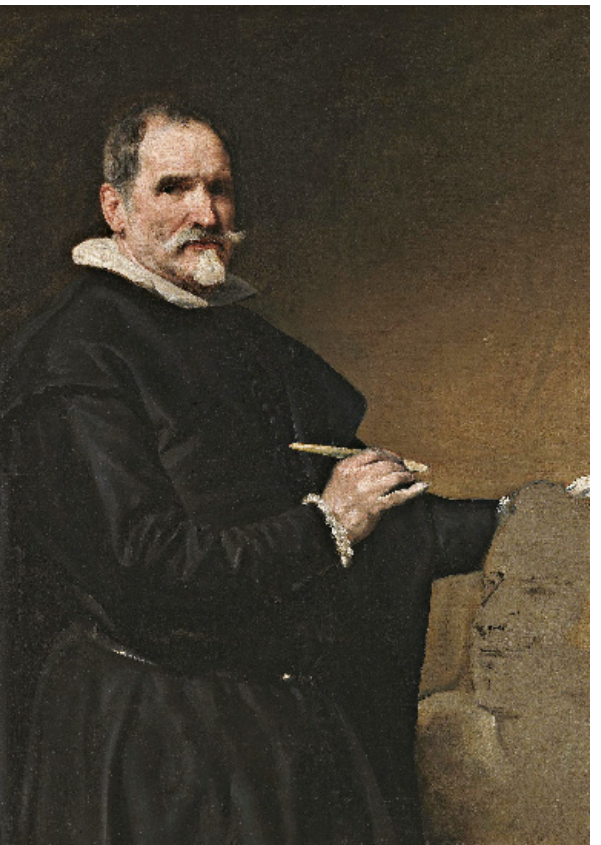

Figura 11. Diego Velázquez, Juan Martínez Montañés (Madrid, 1636). $109 \times$ $88 \mathrm{~cm}$. Óleo sobre lienzo (Museo del Prado, Madrid).

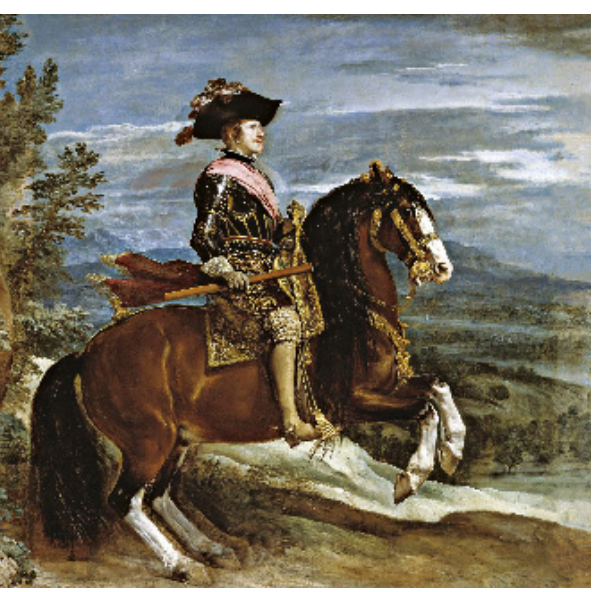

Figura 12. Diego Velázquez, Felipe IV a caballo (Madrid, 1636). Óleo sobre lienzo (Museo del Prado, Madrid). [...y se] construya la nueva fortificación del Presidio del Callao, según el plan de Don Luis Godin [...], de Don Joseph Amich, y de Don Juan Francisco Rossa.

Confirmando que (el 16 de marzo de 1747) con...

[...] la formidable salida del Mar la noche del día 28 de Octubre de 1746 [...] mandé que Don Luis Godin [...] reconociese el Terreno que fuese mas a propósito, formando Plan de ella, y delinease la Fortaleza; y habiendo llegado en la sazón á esta Capital Don Joseph Amich, y Don Juan Francisco Rosa, Peritos en Mathemáticas, y Fortificación, ejecutaron la misma diligencia que Godin; [...] y aunque el marqués de Ovando que concurrió á la delineación, formó otro Plan, no convinieron en él, Godin, Amich, ni Rosa, como ni Yo, ni la Junta de Guerra, [... firma] Joseph Manso»²2.

De los dichos documentos, había transcrito mal Vargas Ugarte (1968, pp. 379 y 466) el nombre de Juan Francisco Rossa leyendo «Juan Francisco Toesca», personaje inexistente a quien atribuye dichas funciones, error que repiten Bernales (1972, p. 315) y muchos otros.

Así, _ como ya decía Estabridis (2012) — «en el siglo XVIII surge la figura del grabador Juan Francisco Rosa, quien lleva a la estampa la imagen del Cristo del Auxilio» aunque, además, - como se ha visto- fue un válido pintor y un excelente «perito en fortificación».

\section{Reflexiones sobre el Crucificado de Lima montañesino, y sobre la «inven- ción»}

Es preciso indagar aún más sobre el significado del Crucificado limeño — representado muerto - revisando el significado que tuvo la imagen del «Cristo muerto» en el erudito y reducido grupo romano quinientista de los «Spirituali» — formado por Miguel Ángel, Victoria Colonna y el cardenal Reginald Pole-que buscaban «la verdad» en las fuentes, grupo afín al «Alumbrado» sevillano, cercano al Montañés. Así, frente al dibujo que — hoy se supone- es el que Miguel Ángel regalara a Victoria Colonna — conservado en Londres - emerge una contradicción; siendo este un «Cristo vivo» que no corresponde al «Tratado [...] del Beneficio de Cristo crucificado» (Venecia, 1543) —-texto base de los Spirituali-que enfatiza la importancia de un «Cristo muerto» que culmina así su importante misión.

Respecto del relativo valor de cada «invención» humana, basta citar la opinión de García Luque (2013) sobre el gran Montañés: «llamado dios de la madera, quien siempre trató de celar sus fuentes reelaborando las composiciones ajenas» (p. 239), verídica e inquietante por su modernidad.

\section{Otra «invención» (técnica): Felipe IV a caballo y su eco en Lima}

Iniciado el Siglo de Oro — prueba de la fama del «imaginero» Martínez Montañés—, estando «en la plenitud de su gloria», como dice el recordado Diego Angulo (1971, p. 279), recibió el encargo «laico» de modelar el busto del reinante Felipe IV (1621-1665) — jinete experto de la Escuela Española de Equitación de Viena, siendo de la Casa de Austriapara un nuevo tipo de estatua ecuestre. El Montañés llegó así a Madrid (1635-1636) y su amigo andaluz el pintor Diego Velázquez —yerno y pupilo del Pacheco — lo retrató mientras esculpía al monarca, buril en mano (ver Figura 11).

22. Sobre Godin, publiqué (Mattos-Cárdenas, 2012, p. 20) su - hasta entonces- desconocido plano de Lima (AGI de Sevilla) que ubica su propuesta para Bellavista —dedicada a los «apóstoles Simón y Judas», día del sisma, en el Santoral—; cuya traza pentagonal — conocida_ igualmente publiqué (Mattos-Cárdenas, 1987, p. 31). 

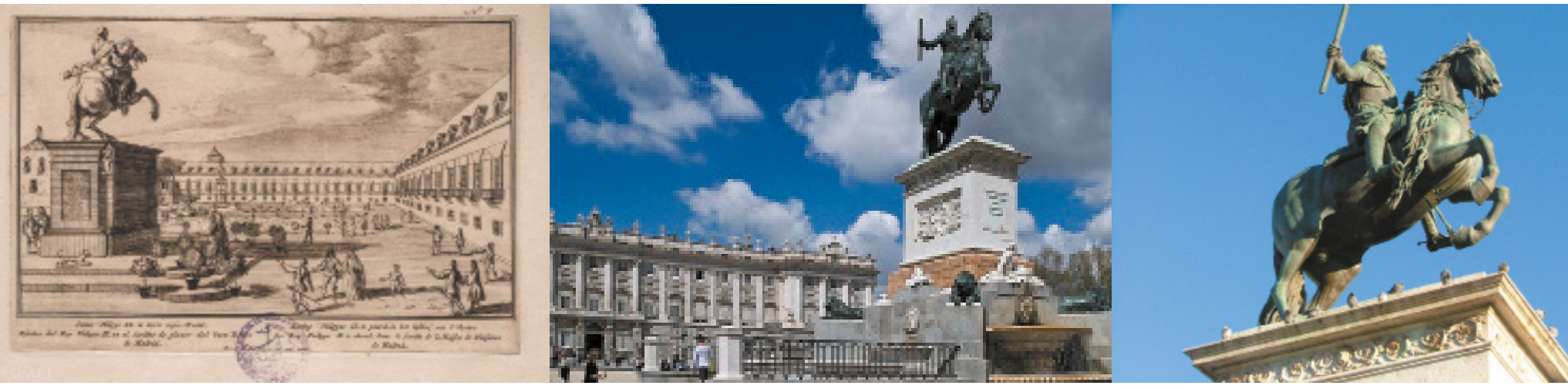

Velázquez — por su parte - ya había pintado un Felipe IV a caballo en Madrid, que «hizo en 30 de Agosto de 1623, a gusto de S. M.» (Pacheco, 1649, p. 102), pero el real deseo era ver - por primera vez - su figura ecuestre esculpida "a corveta», esto es, apoyando sus posteriores mientras la cola toca el suelo. Es testimonio pictórico del modelo - después esculpido- otro Felipe IV a caballo de Velázquez (1635), que empuña de igual manera un idéntico bastón de mando, hoy en el Museo del Prado de Madrid (ver Figura 12).

Del dicho encargo, el «original de Montañés no se conserva» (Angulo, 1971, p. 279). Aunque se sabe que al recibir el busto esculpido por Montañés con la respectiva versión gráfica del Velázquez, Pietro Tacca (Carrara, 1577-Florencia, 1640)23 destruyó su versión iniciada de un caballo al paso y comienza una nueva para satisfacer el real deseo de uno "galopante o en corbeta» — como testimonia el carteo-, posición tan difícil de aplicar a la escultura que Tacca recurrió a la asesoría de Galileo Galilei, como certifica su coevo Filippo Baldinucci ${ }^{24}$.

Dicha estatua llegó (el 29 de octubre de 1642) a los jardines del Buen Retiro en Madrid, pero mudó sucesivamente frente al Palacio Real —a la Plaza de Oriente-, donde hoy la inscripción recita: «Para gloria de las Artes y de la Capital, erigió Isabel Segunda este monumento». Es obra de gusto manierista - a pesar del año de ejecución- por la tensión dinámica y la ágil estructura (ver Figuras 13, 14 y 15)

En Madrid se repropone esta «invención» con un Felipe V a caballo - a tamaño reducido- en periodo neoclásico, homenaje del hijo Carlos III — hoy en la Academia de Bellas Artes de San Fernando- resultado del concurso promovido por él, en ese ente por él creado. Sirvió de modelo, entonces, el caballo «Aceitunero», como se lee en su pedestal (ver Figura 16).

Dicha «invención» tuvo eco en Lima, gracias a grabados del Buen Retiro con Felipe IV a caballo en diferentes angulaciones. En lienzo está presente en el Conde de Lemos a caballo con el estandarte de Santa Rosa, quien gobernando (1667-1672) fue testigo de su beatificación y canonización, antes de morir - a los 38 años-en Lima25 (ver Figura 17).

23. Tacca antes completaba la estatua de Felipe III —al paseo y no a «corveta»—, hoy en la plaza mayor de Madrid.

24. Notizie dei Professori del Disegno da Cimabue in qua, publicado en Florencia y con acceso online en https://books.google.it/books/about/Notizie de professori del disegno da Cim.html?id=jVsGAAAA-

QAAJ\&redir_esc $=y$

25. Pintor anónimo; expuesta en el museo Enrique Larreta (Buenos Aires, Argentina).
Figura 13. Felipe IVen el Jardin del Buen Retiro de Madrid . Grabado de Louis Meunier (c. 1686) $10 \times 20,9 \mathrm{~cm}$. Uno de los muchos grabados, entonces, en circulación (www.memoriademadrid.es).

Figura 14. Felipe IV a caballo frente al Palacio Real, Madrid. Fotografia de mediados del siglo pasado (www.memoriademadrid.es).

Figura 15. Pietro Tacca, Felipe IV a caballo (Florencia, 1639). Plaza de Oriente, Madrid (LMC, 2010). 

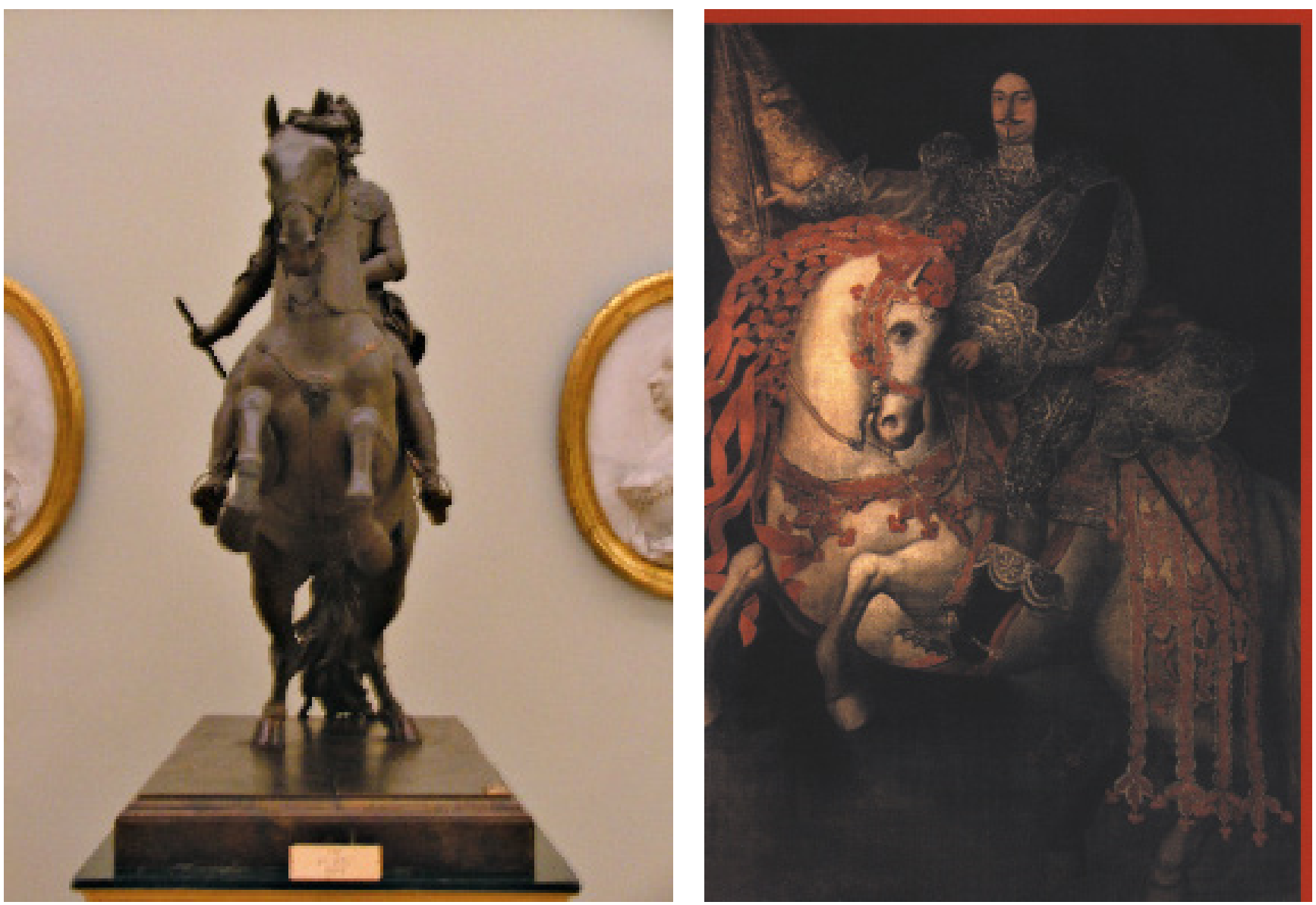

Figura 16. Manuel Francisco Alvarez, Felipe V a caballo (Madrid, 1778). Inciso en la peana se lee: «Este modelo del caballo está arreglado a la simetría y proporción que da el natural del caballo Aceitunero del príncipe No Sr». Academia de Bellas Artes de San Fernando, Madrid (LMC, 1988).

Figura 17. Anónimo, El Conde de Lemos con el estandarte de Santa Rosa (Lima, XVII). Museo Larreta, Buenos Aires.
Incluso, está presente en dos figuras a tinta sobre carta de Santiago de Taboada (firmando como D. Jacob. d. Taboad): un Francisco Pizarro a caballo (Lima, 1697) ${ }^{26}$ que — con otras figuras - ilustra el Poema a Santa Rosa del Conde de la Granja — quien «obtuvo este titulo por R.C. de 12 de junio de 1683, en premio de sus servicios en el Perú, especialmente como Gobernador de Potosí» (Vargas Ugarte, 1965, p. 35)-, y un Santiago Matamoros a caballo (c. 1686), que a corveta defiende el Cusco, en 1536, contra Manco Inca - documento este último en el mercado del arte-que ilustra, con otros, un Expediente de hidalguía del abogado de la audiencia limeña Marcelo de Ayala Marín Benavides y Arce (ver Figuras 18 y 19).

Igualmente, algunas esculturas ecuestres a corveta hicieron también acto de presencia en Lima, como se deduce de los títulos que siguen.

\section{El Arco del Puente de Lima con —Felipe V a caballo-, escultura de Balta- sar Gavilán}

Aplicó dicha «invención» el escultor mestizo Baltasar Gavilán (1739), conocido por su estatua de la muerte, que para desarrollar su propósito se sirve de los conocidos grabados y del testimonio del mismo virrey que vino de Madrid, donde estaba el Felipe IV a caballo. Esculpió en madera su Felipe $V$ a caballo, el cual colocó en Lima -con otras esculturas-en el nuevo arco de ingreso sobre el Puente de Piedra. Se trata de 


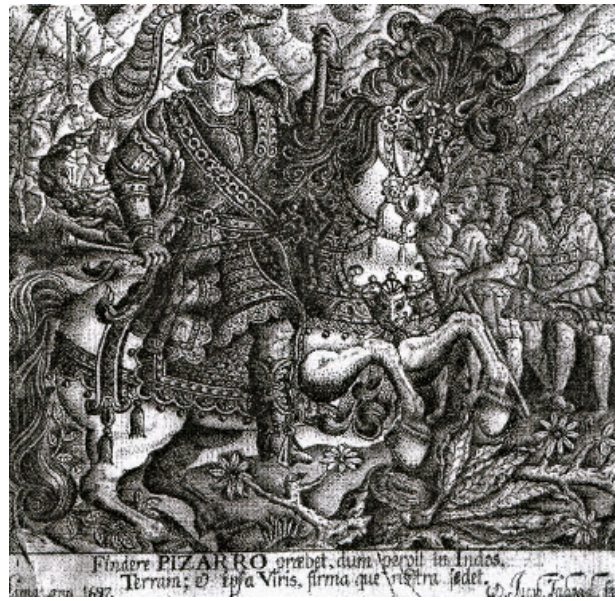

Figura 18. Santiago de Taboada, Francisco Pizarro a caballo (Lima, 1697). Biblioteca Lázaro Galdiano, Madrid (Mujica, 2016, p. 189).

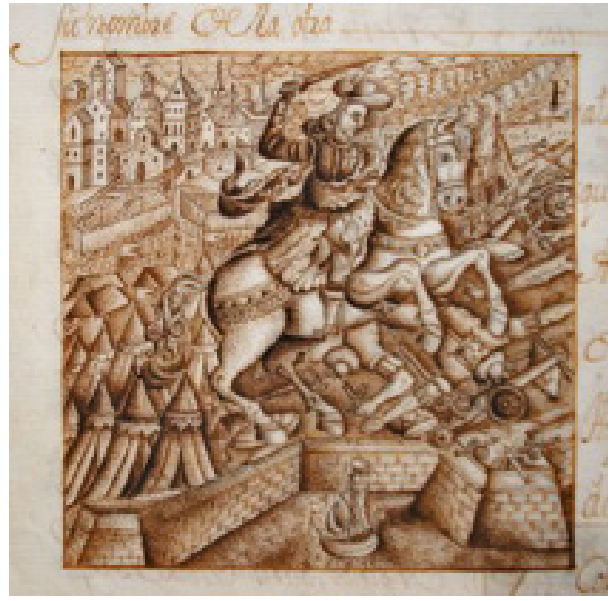

Figura 19. Santiago de Taboada, Santiago Matamoros en Cusco contra Manco Inca (Lima, c. 1686). Gabinete, Salón del Coleccionista de Dibujos y Estampas, stand G5, Madrid; cat. N. 3 www.bookartfine.com www. arteygrafia.com

una obra perdida, inaugurada por el virrey marqués de Villagarcía en su tercer año de gobierno (1736-1745).

El dicho arco es de orden dórico; en él alternan triglifos y metopas con bucráneos y otras figuras. El grabado que lo reproduce fue presentado a un simposio en el año 2000 por Francisco Statsny (2005, p. 212) detallando dicha obra, incisa en una lámina de cobre, posteriormente cortada para hacer dos semióvalos como soportes para futuras pinturas (ver Figura 20 y 21).

Si bien Statsny analiza la obra con una óptica algo diferente, en el semióvalo superior vemos - de frente- al Felipe V a caballo en posición «a corveta», idéntico al Felipe IV a caballo madrileño, que viste coraza guerrera con bastón de mando en la mano derecha. El animal, como ha sido descrito, apoya posteriores, mientras la cola trabaja a la tracción. En las esquinas superiores — derecha e izquierda- aparecen encerradas, en pequeños óvalos verticales algo mutilados, dos figuras ecuestres - a tres cuartosque repiten dicha posición. El arco culmina con un plano horizontal con balaustras de madera - seguramente-, ya que las sucesivas balaustras del puente fueron de madera. Al centro, la estatua ecuestre del rey, flanqueada por dos felinos rampantes de madera probablemente, que son parte de su emblema heráldico, y a los extremos se observan pináculos, de moda por los grabados del Escorial (XVI), presentes en portadas cusqueñas (Almirante, Cuatro Bustos) y en Lima, en la portada lateral de San Francisco y en la portada-retablo del ingreso al dicho convento (1674), ambas obras de don Manuel de Escobar.

La plancha del dicho grabado recita lo siguiente: «El Exmo. Sr. Marques de Villa Garcia, siendo virrey, mandó coronar este arco y poner en él la estatua del rey nuestro Señor don Phelipe Quinto ¡Que Dios guarde! Cometió la obra al Sr. Marqués de Cassaconcha, oydor decano de esta Real Audiencia de Lima año de 1739»; además, allí se lee que el arco mide «20 baras» $(16,71 \mathrm{~m})$ de ancho, con gruesos pilares rectangulares, bases del arco de medio punto. Probablemente la entera arquitectura del arco fue igualmente de Baltasar Gavilán, «figura todavía misteriosa», escribe Schenone (1980, p. 439). La obra es poco conocida, ya que estuvo en pie solo siete años y el gran terremoto de 1746 la destruyó. Un reciente estudio (Ravines, 2016, p. 84) sobre el espacio donde estuvo dicho arco con su escultura - la Plaza de Los Desamparados - ignora esta obra, además afirmando impropiamente que existía allí, ya en 1535, un puente, 


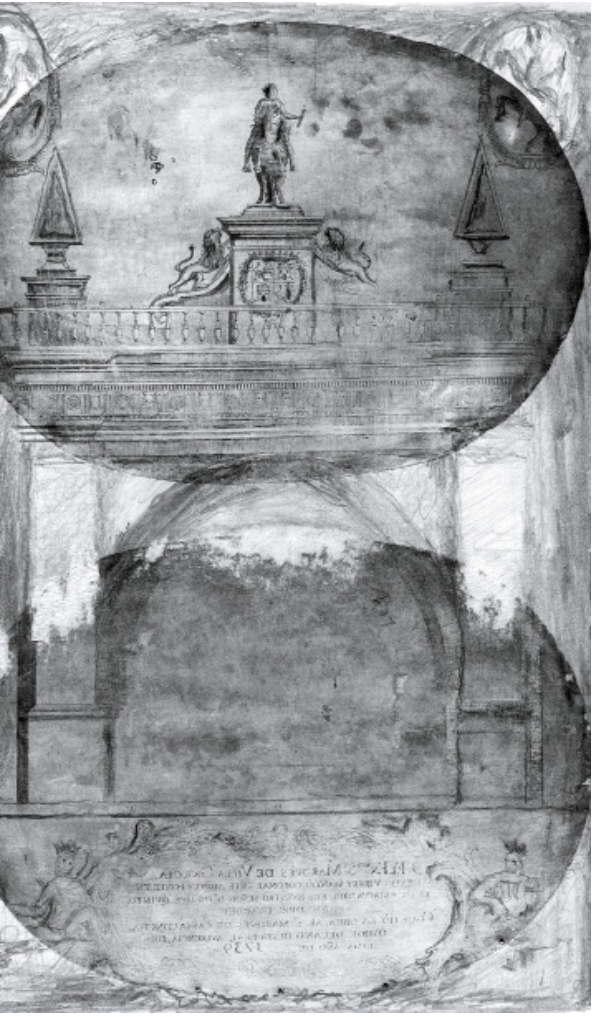

Figura 20. Arco del Puente de Piedra (Lima, 1739-1746) —reconstrucción gráfica- según las láminas que lo ilustraban (LMC, 2018).

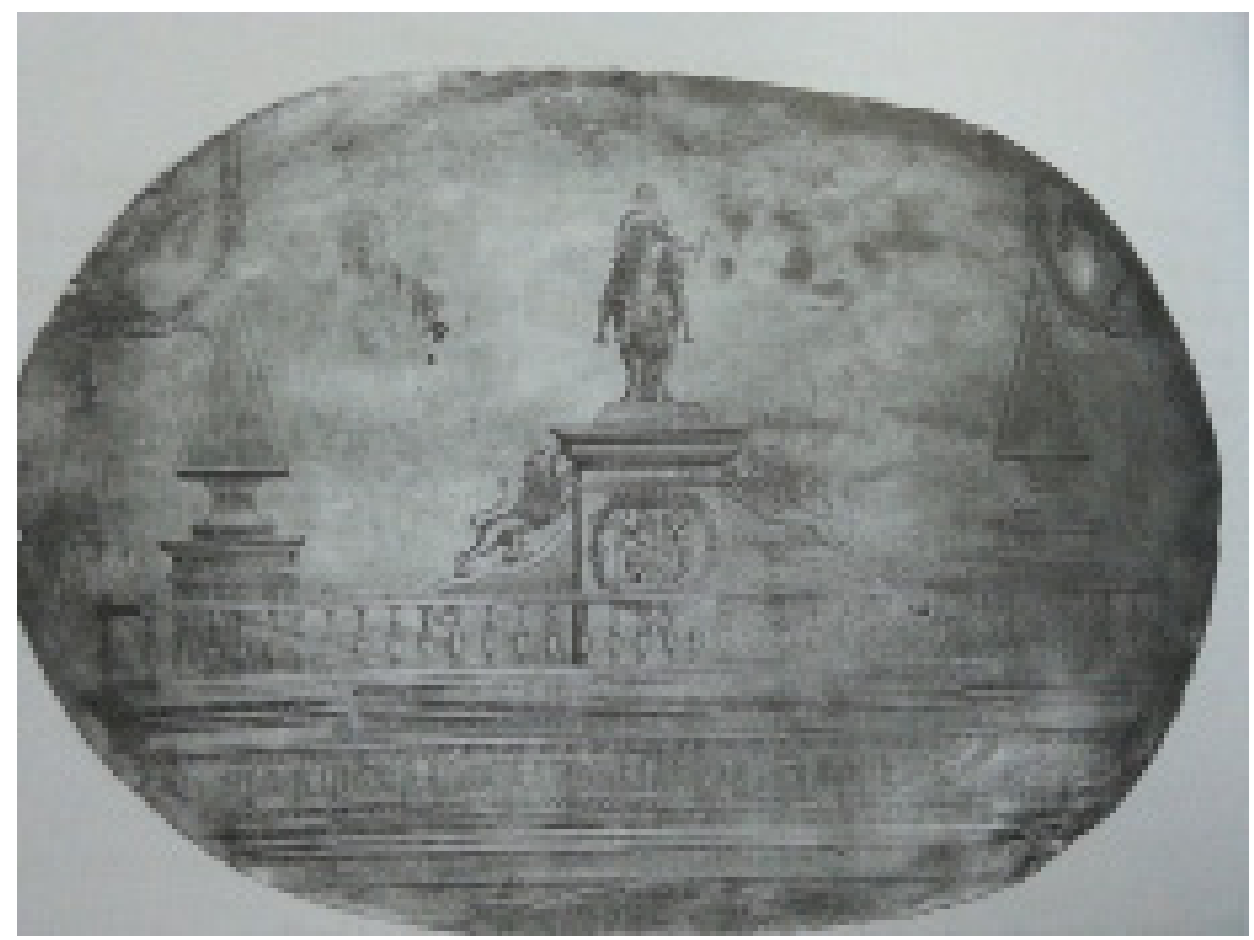

Figura 21. Arco del Puente de Piedra —-sector del grabado en cobre — con Felipe V a caballo (Lima, 1739) de Baltasar Gavilán (Stastny, 2005, p. 216).

mientras el único puente existente entonces era uno de criznejas y no estaba allí sino cerca del hoy Puente del Ejército (Mattos-Cárdenas, 2004a, pp. 67-68) ${ }^{27}$.

\section{La estatua ecuestre del rey (1765) para el Paseo de Aguas de Lima}

La «invención» se repropone cual fondo escenográfico del primer proyecto para el Paseo de Aguas que el virrey Manuel de Amat (1761-1776) programó para la capital. El motivo central, con la estatua ecuestre (1765), se presume haya sido del reinante Carlos III. Su caballo en idéntica posición a corveta apoya sus patas posteriores con la cola funcionando como tirante, como se observa en dicho dibujo de acuarela, que parece obra del mismo virrey. La estatua - que presumo de bronce- está ubicada sobre un alto podio y surgen a lo largo de su base varios vertederos de agua en serie. Además, es flanqueada por sendas fuentes - previstas seguramente en bronce- de tres tazas cada una (ver Figura 22).

Esas características las noté en uno de los grandes cartones a la acuarela que Amat llevó consigo a su tierra natal y que hoy se conservan (Biblioteca de Cataluña, Ms $400,124)$. Dicha lámina - como las restantes-carecía de ubicación clara en el contexto general $-y$ de un nombre específico-, condiciones que definimos al publicarlas (Mattos-Cárdenas, 2004a, p. 103).
27. Dicho estudio ofrece este dato erróneo, que parece provenir de dibujos (no corregidos) del arq. Gunther, quien había supuesto un único puente existente cerca de la plaza principal; antes de que le informe, en 1982, del correcto trazo del Cápac-ñam costeño, dentro de Lima amurallada, traza que era desconocida — hasta dicha fecha - por Gunther, por Harth-Terré, por Bernales (1972) — cuya reconstrucción de Lima en tiempos del virrrey Cañete (pp. 40-41) lo ignora-, y por Juvenal Baracco, testigo de lo afirmado. 


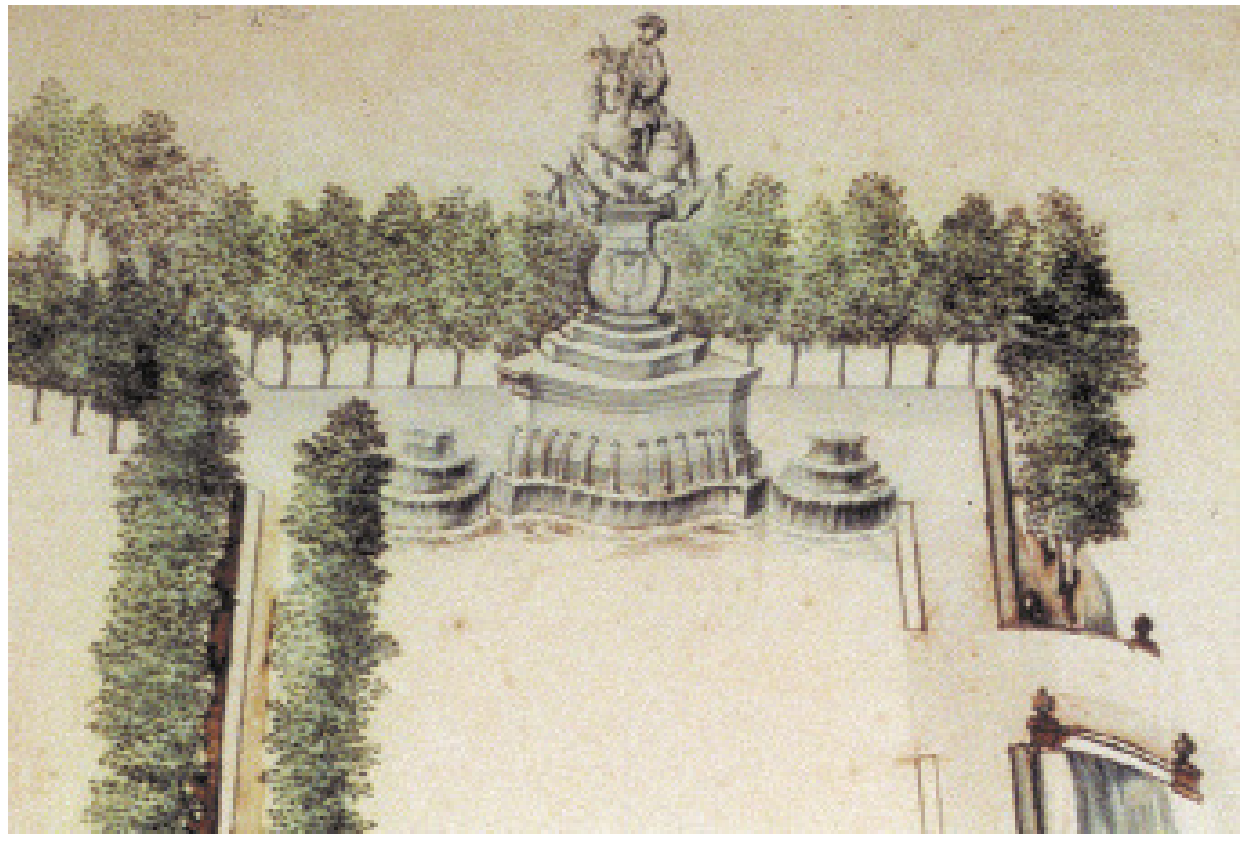

Figura 21. Paseo de Aguas de Lima — detalle central con Estatua ecuestre del rey—Primera propuesta (Lima, 1764). Biblioteca de Cataluña Ms. 400, Barcelona (Mattos-Cardenas, 2004a, p. 103)

La obra hoy existente, que dejó inconclusa Amat — por su improviso regreso-, la pude atribuir al autor de la plaza de toros de Acho, el conocido alarife Cristóbal de Vargas (Mattos-Cárdenas 2016, p. 41), debido a que tiene módulos similares «b-a-b», presentes en la - antes existente- columnata en Acho (de madera), así como en el actual esquema de columnas (en piedra) de dicho paseo. Ambas presentan, además, idénticos planos escalonados: el frontis del actual Paseo de Aguas y la puerta de ingreso al actual coso de Acho.

\section{La estatua ecuestre de Bolívar en la antigua plaza limeña}

En Lima, se aprecia finalmente dicha «invención», gracias al escultor Adamo Tadolini (Bolonia, 1788-Roma, 1868), que repropone este prototipo para su estatua en bronce dedicada al libertador Simón Bolívar. Otros modelos en yeso, alternativos de dicho encargo, se conservan en el taller romano del artista en Via del Babuino, obra fundida en bronce en Múnich (Alemania) ${ }^{28}$.

En efecto, el Congreso de la República había decretado la erección de dicha escultura ya en 1825 (Mattos-Cárdenas, 2004a, p. 197). Al darse el «cúmplase» de dicha ley en 1853, las gestiones fueron encargadas a Bartolomé Herrera, diplomático peruano en Roma.

La estatua ecuestre de Bolívar —donde colaboró su hijo Scipione Tadolini-, a poco tiempo de su llegada al Callao, se inauguró en Lima (diciembre de 1859) en la plaza «de la Inquisición» o también llamada «Plaza de la Constitución de Cádiz» a finales de la Colonia ${ }^{29}$ (ver Figura 23).

28. Tadolini hizo el dicho modelo en su atelier, que fuera hasta 1818 de Antonio Canova; copia del Bolívar a escala reducida en bronce posee la casa Urquiaga de Trujillo (Perú).

29. El Bolívar de Tadolini fue declarado Patrimonio Cultural de la Nación en mayo de 2018; una réplica suya fue inaugurada (1874) en Caracas y otra, el pasado siglo, en la ciudad de San Francisco, EE. UU. 
devenir Vol. 6, N¹2, JULIO - DICIEMBRE 2019, PP. 27-46 - EstudIOS I ISSN 2312-7562 | E-ISSN 2616-4949

UNIVERSIDAD NACIONAL DE INGENIERÍA, LIMA

doi: https://doi.org/10.21754/devenir.v6i12.742

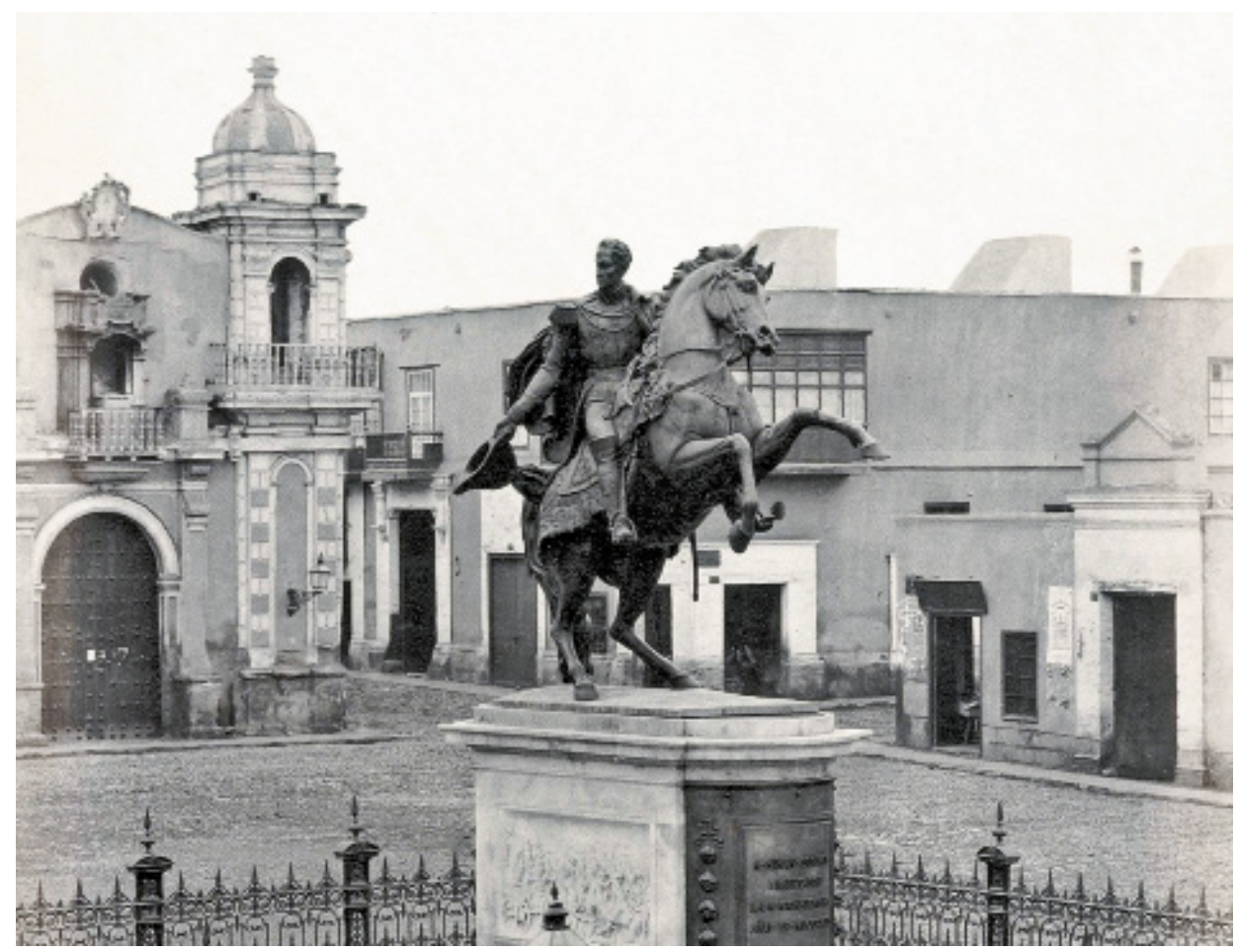

Figura 23. La Plaza Bolívar en Lima (Estudio Courret Hermanos, 1876).

La fotografía que se publica, tomada hacia 1876, muestra edificios - al fondo a la izquierda- que a inicios del siglo pasado fueron reemplazados por el actual edificio del Congreso. Sin embargo, detrás de la estatua de Bolívar se nota la única vivienda que sobrevive en la misma esquina de dicha plaza, gracias a la válida restauración - hace algunas décadas - del arquitecto José Correa Orbegoso, compañero de actividades y de estudios en Lima y Europa. Sea el presente estudio un homenaje a su memoria y a su proficua actividad.

\section{Referencias}

Angulo, D. (1971) Historia del Arte. Madrid; Distribuidor E.I.S.A.

Aparicio, S. (1997). Los mercedarios en la evangelización del Perú. En S. Peredo Meza (Ed.), La Orden de La Merced en el Perú, Estudios (pp. 7-132). Roma: Instituto Histórico de la Orden de La Merced.

Barriga, V. M. (1941). El templo de La Merced de Lima. Arequipa: Establecimientos Gráficos La Colmena.

Basadre, J. (1945). El conde de Lemos y su tiempo. Lima; Empresa Gráfica Scheuch.

Bernales Ballesteros, J. (1972). Lima. La ciudad y sus monumentos. Sevilla: Escuela de Estudios Hispano-Americanos.

Bernales Ballesteros, J. (1980). Portadas y retablos en Lima durante los siglos XVII y XVIII. En Simposio internazionale sul Barocco Latino Americano (Vol. I, pp. 501-537). Istituto Italo-Latino Americano. Roma:Tipografía Cruciani.

Bernales Ballesteros, J. (1981). Escultura montañesina en América. En Anuario de estudios americanos (Tomo XXXVIII, pp. 499-566). Sevilla: Escuela de Estudios Hispano Americanos.

Bernales Ballesteros, J. (1987). Historia del arte hispanoamericano (Tomo 2). Siglos XVI a XVIII. Madrid: Alhambra. 
Chacón, M. (1973). Arte virreinal en Potosí. Sevilla: Escuela de Estudios Hispano-Americanos.

de Mesa, J., y Gisbert de Mesa, T. (1985). El arte del siglo XVII en Perú y Bolivia. En Summa Artis XXVIII (pp. 314-435). Madrid: Editorial Espasa-Calpe.

Estabridis, R. (2012). El grabado en Lima virreinal. Documento histórico y artístico (siglos XVI al XX). Lima: Fondo Editorial de la UNMSM.

García Luque, M. (2013). Fuentes grabadas y modelos europeos en la escultura andaluza. En La consolidación del Barroco en la escultura andaluza e hispanoamericana (pp. 181-258). Universidad de Granada.

Harth-Terré, E. (1957, 2 de abril). El Crucificado del Montañés en el Perú. El Comercio (edición vespertina), p. 4. Lima.

Harth-Terré, E. (1962). Una escultura de Martínez Montañés en Lima. Cuadernos Hispanoamericanos, 152-153, Agosto-Septiembre, pp. 261-271. Madrid.

Harth-Terré, E. (1977). El Crucificado de Montañés y los escultores de crucificados. En Escultores españoles en el Virreinato del Perú (pp. 90-97). Lima: Ed. Mejía Baca.

Hazañas y La Rua, J. (1918). Vazquez de Leca 1573-1649. Sevilla: Imprenta sobrinos de Izquierdo. Recuperado de https://ia802706.us.archive.org/7/items/vzquezdeleca1500hazauoft/ vzquezdeleca1500hazauoft.pdf

Hernández Díaz, J. (1949). Martínez Montañés. Laboratorio de Arte. Universidad de Sevilla.

Hernández Díaz, J. (1965). Martínez Montañés en Lima. Anales de la Universidad Hispalense XXV (pp. 100-101). Sevilla.

Interian de Ayala, J. (1782). El pintor christiano, y erudito, ó tratado de los errores que suelen cometerse freqüentemente en pintar, y esculpir las Imágenes Sagradas (Tomo 1.o, Libro 3.o, cap. XVII). Madrid. Recuperado de http://www.cervantesvirtual.com/obra-visor/el-pintor-christiano-y-erudito-o-tratado-de-los-errores-que-suelen-cometerse-frequentemente-en-pintar-y-esculpir-las-imagenes-sagradas--0/html/ff4568c4-82b1-11 df-acc7002185ce6064_164.html

Marqués de Lozoya (1945). Historia del arte hispánico (Tomo 4). Barcelona: Editorial Salvat.

Marqués de Lozoya. (1948). Estudios recientes sobre arte hispánico. Cuadernos Hispanoamericanos, 2, pp. 311-315. Madrid: Editorial Mundo Hispánico.

Marqués de Lozoya. (1971). Montañés en Indias. En Martínez Montañés (1568-1646) y la escultura andaluza de su tiempo. Madrid.

Mattos-Cárdenas, L. (1987). El limeño Olavide y el urbanismo hispanoamericano. En Documentos de Arquitectura y Urbanismo (DAU), 2/3, 30-78. Lima.

Mattos-Cárdenas, L. (2004a). Urbanismo andino e hispanoamericano. Ideas y realizaciones (15301830). Lima: INIFAUA, UNI.

Mattos-Cárdenas, L. (2004b). Utopías y realidades en la Lima del siglo XVIII. El Perú. Las culturas del sol [Catálogo de la exposición] (pp. 125-131). Barcelona: SEACEX, Agencia de Cooperación Española. Recuperado de http://www.seacex.com/documentos/peru_19_utopia.pdf

Mattos-Cárdenas, L. (2012) Lima virreinal. Orígenes y desarrollo de una ciudad compleja. En Lima. The historic center. Analysis and restoration (pp. 18-23). Roma: Editorial Gangemi, Universidad La Sapienza. Recuperado de http://www.gangemi.com/documentos??.pdf

Mattos-Cárdenas, L. (2016). El plano inédito de la «Casona» de San Marcos y la obra de Cristóbal de Vargas (siglo XVIII). El «módulo b-a-b» y su recuperación. Devenir, 3(5), 28-44.

Mattos-Cárdenas, L. (2017). Lima y la Plaza de Armas. Historia y aportes de Emilio Harth-Terré. Lima. Colegio de Arquitectos del Perú, regional Lima, FAUA-UNI.

Mujica Pinilla, R. (2016). La imagen trasgredida. Ensayos de iconografía peruana y sus políticas de representación simbólica. Lima: Fondo Editorial del Congreso.

Pacheco, F. (1649). Arte dé la Pintvra. sv antigvedad, y grandezas. [...]. Sevilla: Simón Faxardo impresor. Recuperado de https://archive.org/stream/HArteR03T09/HArteR03T09_djvu.txt 
devenir Vol. 6, Nº12, JULIO-DICIEMBRE 2019, pP. 27-46 - Estudios I ISSN 2312-7562 | E-ISSN 2616-4949 UnIVERSIDAD NACIONAL DE INGENIERÍA, LIMA

doi: https://doi.org/10.21754/devenir.v6i12.742

Ramos Sosa, R. (2000). Martín Alonso de Mesa, escultor y ensamblador (Sevilla c. 1573-Lima 1626). Anales del Museo de América, 8, 45-63, Madrid.

Ravines Casas, J. (2016). La plazuela de Los Desamparados y su entorno monumental. Valorización histórica de la construcción de un lugar. Devenir, 3(6), 79-89.

San Cristóbal, A. (1994). Fray Cristóbal Caballero y la portada de La Merced de Lima. Anuario de Estudios Americanos (Tomo XDVIII, pp. 313-353). Sevilla: Escuela de Estudios Hispano-Americanos.

Schenone, H. (1950). Notas sobre arte renacentista en Sucre. Anales del Instituto de Arte Americano, 3, 33-52, Buenos Aires.

Schenone, H. (1980). La escultura sevillana en Lima. Simposio Internazionale sul Barocco Latino Americano. Istituto Italo-Latino Americano (Vol. I, pp. 429-439). Roma: Tipografia Cruciani.

Stastny, F. (2005). From fountain to bridge: Baroque projects and Hispanism in Lima. Studies in the History of Art, 66, 206-224. Symposium papers XLIII. Architecture in Europe and in the Americas.

Vargas Ugarte, R. (1965) Títulos nobiliarios en el Perú (4 ed.). Lima: Librería e Imprenta Gil S. A.

Vargas Ugarte, R. (1968). Ensayo de un diccionario de artífices de la América Meridional (2 ed. corregida y aumentada). Burgos: Imprenta Aldecoa. 